\title{
POLA BAKTERI AEROB DAN UJI KEPEKAAN TERHADAP ANTIBIOTIKA PADA PENDERITA OTITIS MEDIA DI POLIKLINIK THT-KL BLU RSUP PROF. DR. R. D. KANDOU MANADO PERIODE DESEMBER 2012 - JANUARI 2013
}

\author{
${ }^{1}$ Alke Rumimpunu \\ ${ }^{2}$ Constantyn Kountul \\ ${ }^{2}$ Velma Buntuan \\ ${ }^{1}$ Fakultas Kedokteran Universitas Sam Ratulangi \\ ${ }^{2}$ Bagian Mikrobiologi Kedokteran Universitas Sam Ratulangi \\ Email: alke.anastacia@gmail.com
}

\begin{abstract}
Otitis Media, an infection of middle ear, is one of the health problems that can cause hearing loss to total deafness. The causes of otitis media are inter alia infections of the aerob bacteria. In Indonesia, the incidence of otitis media is 3.9-6.9\%. Patience compliance due to treatment, germ resistance, anatomy of the ear, and complications lead to difficulties in terms of treatment of the otitis media itself. This study aimed to determine the pattern of bacteria and their susceptibility to antibiotics in patients with otitis media. This was a descriptive prospective study with samples of 20 patients diagnosed with otitis media who met the inclusion criteria. The patients' ear discharge was used for identifiaction and culture of bacteria in blood agar, nutrient agar and McConkey agar. Gram staining was used for bacteria identificatiion. Levofloxacin and cyprofloxacin were used for antibiotic sensitivity test. Conclusion: The identified bacteria were Staphylococcus aureus, Enterobacter Aerogenes, Staphylococcus Epidermitis, Proteus vulgaris, Cibrobacter divertus, Alcaligenes falcelus, and Pseudomonas aeruginosa. Bacterial growth were mostly found in children. Almost all bacteria were sensitive to both antibiotics, but they were fairly resistant to clindamycin and erythromycin.
\end{abstract}

Keywords: patterns of bacteria, sensitivity test, otitis media

\begin{abstract}
Abstrak: Otitis media merupakan salah satu gangguan kesehatan telinga yang dapat menyebabkan gangguan pendengaran hingga tuli. Gangguan pada otitis media terletak di telinga bagian tengah. Penyebab otitis media antara lain infeksi bakteri aerob. Di Indonesia, angka kejadian otitis media sebesar 3,9-6,9\%. Ketidakpatuhan penderita dalam perawatan, kuman yang resisten, bentuk anatomi telinga, dan adanya komplikasi menyebabkan kesulitan dalam hal pengobatan dan perawatan otitis media. Penelitian ini bertujuan untuk mengetahui pola bakteri dan kepekaannya terhadap antibiotika pada penderita otitis media. Penelitian ini bersifat deskriptif prospektif dengan sampel sebanyak 20 pasien yang didiagnosis otitis media yang memenuhi kriteria inklusi. Sekret telinga diambil untuk identifikasi kuman dan kultur pada agar darah, agar nutrien, dan agar McConkey. Pengecatan Gram dilakukan untuk identifikasi kuman dan uji kepekaan dilakukan terhadap antibiotika levofloxasin dan ciprofloxasin. Simpulan: Bakteri yang diidentifikasi yaitu Staphylococcus aureus, Enterobacter Aerogenes, Staphylococcus Epidermitis, Proteus vulgaris, Cibrobacter divertus, Alcaligenes falcelus, dan Pseudomonas aeruginosa. Pertumbuhan kuman tersering ditemukan pada anak-anak. Hampir semua bakteri peka terhadap antibiotika levofloxacin dan ciprofoxacin tetapi memperlihatkan tingkat resistensi cukup tinggi terhadap clindamycin dan eritromycin.
\end{abstract} Kata kunci: pola bakteri, uji kepekaan, otitis media 
Otitis media merupakan salah satu gangguan kesehatan telinga yang dapat menyebabkan gangguan pendengaran hingga bisa tuli, bahkan dapat mengancam jiwa sehingga mempunyai dampak yang merugikan bagi penderita, keluarga, dan masyarakat. Saat pendengaran mulai berkurang dan mengganggu aktivitas sehari-hari barulah mencari bantuan medis, sehingga tak jarang telah menimbulkan komplikasi. Gangguan pada otitis media terletak di telinga bagian tengah. Penyebab otitis media adalah multifaktorial, antara lain infeksi bakteri, virus, gangguan fungsi tuba, alergi, kekebalan tubuh, lingkungan, dan faktor sosial ekonomi. ${ }^{1}$

Otitis media terdapat pada semua bangsa diseluruh dunia baik di negara berkembang maupun negara maju dengan angka kejadian bervariasi. Di negara-negara berkembang angka kejadian jauh lebih tinggi karena beberapa hal misalnya higiene yang kurang, faktor sosioekonomi, gizi yang rendah, kepadatan penduduk serta masih ada pengertian masyarakat yang salah terhadap penyakit ini sehingga mereka tidak berobat sampai tuntas. ${ }^{2,3}$

Di Amerika Serikat, otitis media terdiagnosis lebih dari 5 juta kali setiap tahunnya, dan merupakan alasan paling banyak dituliskannya resep antibiotik untuk anak-anak. Di Australia, tiap tahunnya 3-5\% anak meninggal akibat komplikasi otitis media dan 15 anak menderita kehilangan pendengaran permanen akibat otitis media. Di Indonesia sendiri angka kejadian otitis media sebesar 3,9-6,9\%.,

Otitis media dalam klasifikasinya terbagi atas; pertama otitis media supuratif yaitu otitis media supuratif akut atau otitis media akut dan otitis media supuratif kronik. Kedua otitis media non supuratif atau otitis media serosa yaitu otitis media serosa akut (barotrauma atau aerotitis) dan otitis media serosa kronik (glue ear), ketiga otitis media spesifik seperti otitis media sifilitika atau otitis media tuberkulosa, dan terakhir otitis media adhesiva. Adapun bakteri aerob penyebab otitis media yaitu Staphylococcus aureus, Pneumokok, Haemofilus influenza, Escherichia coli, Streptococcus anhemolitikus, Streptococcus hemolyticus, Proteus vulgaris dan Pseudomonas aeruginosa. ${ }^{5}$

Keberhasilan pengobatan penyakit infeksi bakteri dengan antibiotik pada dasarnya merupakan hasil akhir dari 3 komponen, yaitu penderita, bakteri dan antibiotika. Hal ini disebabkan karena penyakit infeksi bakteri adalah manifestasi klinik dari interaksi antara penderita dan bakteri. Adapun untuk pengobatan infeksi dibutuhkan antibiotika yang tepat dan daya tahan tubuh penderita itu sendiri. Memilih antibiotika yang tepat dapat dilakukan berdasarkan pengetahuan tentang jenis bakteri penyebab penyakit dan akan lebih baik lagi apabila disertai adanya hasil uji kepekaan pemeriksaan mikrobiologi. Ketidakpatuhan penderita dalam perawatan, kuman yang resisten, bentuk anatomi telinga, adanya komplikasi, menyebabkan kesulitan dalam hal pengobatan dan perawatan penderita otitis media. $^{6}$

Berdasarkan angka kejadian yang cukup tinggi, serta kemungkinan terjadi resistensi terhadap antibiotika dan bervariasinya pola kuman pada penyakit otitis media sehingga penulis tertarik untuk melakukan penelitian mengenai pola kuman dan kepekaannya terhadap antibiotika pada penderita otitis media.

\section{METODE PENELITIAN}

Penelitian ini bersifat deskriptif prospektif yaitu untuk mendapatkan pola bakteri dan kepekaannya terhadap beberapa antibiotika dari sekret telinga otitis media. Penelitian ini dilaksanakan pada bulan Desember 2012 - Januari 2013 dengan lokasi pengambilan sampel dilakukan di Poliklinik THT-KL BLU RSUP Prof. Dr. R. 
D. Kandou Manado dan pemeriksaan sampel dilakukan di Laboratorium Mikrobiologi BLU RSUP Prof. Dr. R. D. Kandou Manado.

Kriteria Inklusi dalam penelitian ini yaitu sampel penderita baru yang datang memeriksakan diri dan berobat ke Poliklinik THT-KL BLU RSUP Prof. Dr. R. D. Kandou Manado yang didiagnosa menderita otitis media. Sedangkan kriteria ekslusi yaitu penderita otitis media yang telah menggunakan antibiotika. Variabel Penelitian terdiri dari umur, jenis kelamin, bakteri dalam sekret telinga otitis media, dan kepekaan terhadap antibiotika. Sampel penelitian 20 orang merupakan pasien yang memeriksakan diri ke poliklinik THT-KL yang didiagnosis penderita otitis media rentan usia mulai dari 6 bulan sampai 77 tahun. Dari 20 sampel, 9 (45\%) sampel diambil dari pasien dengan jenis kelamin laki-laki dan pasien dengan jenis kelamin perempuan berjumlah 11 orang (55\%).

Sampel diambil dengan cara mengusapkan lidi pada liang telinga, diambil sekretnya, dimasukkan ke dalam media transport Stuart lalu di bawa ke laboratorium mikrobiologi BLU RSUP Prof Dr. R. D. Kandou untuk dibiakkan (dikultur). Untuk menentukan bentuk kuman dan apakah gram negatif atau positif, dilakukan pengecatan gram.

Selanjutnya dilakukan uji kepekaan. Kuman diperbanyak di dalam tabung yang mengandung kaldu selama 8-24 jam lalu disimpan dalam inkubator kemudian kuman dipindahkan ke Mueller Hitton (MH) dengan cara lidi kapas diambil dari kaldu lalu dioles pada pemukaan media $\mathrm{MH}$. Cakram obat antibiotika diletakan pada media kuman (lempeng agar) dengan jarak yang diatur sedemikian rupa sehingga memudahkan untuk melihat hasil. Tekan cakram tersebut pada permukaan agar, supaya obat dapat meresap ke dalam agar yang baik. Jarak antara cakram satu dengan yang lain sekurang-kurangnya $3 \mathrm{~cm}$ dan $2 \mathrm{~cm}$ dari pinggir, disimpan dalam suhu $37^{\circ} \mathrm{C}$ selama 24 jam. Ditentukan adanya zona hambatan berupa zona terang atau tidak ada zona hambatan disekitar obat antibiotika. Jika diukur dalam milimeter dan dibandingkan dengan daftar klasifikasi zone diameter menurut National Committee for Clinical Laboratory Standart/NCCLS. Hal ini untuk mengetahui apakah kuman sensitif, intermediate atau resisten terhadap obat antibiotika yang digunakan. ${ }^{7}$

\section{HASIL DAN BAHASAN}

Setelah dilakukan penelitian tentang pola kuman dan uji kepekaan antibiotika terhadap 20 sampel penderita baru yang didiagnosis otitis media di Poliklinik THTKL BLU RSUP Prof. Dr. R. D. Kandou Manado selama periode Desember 2012 Januari 2013 didapatkan 18 sampel yang mengalami pertumbuhan bakteri dan 2 sampel tidak ada pertumbuhan bakteri. Dari 18 sampel bakteri yang bertumbuh dan yang berhasil diidentifikasi adalah Staphylococcus aureus, Enterobacter aerogenes, Staphylococcus epidermitis, Proteus vulgaris, Citrobacter diversus, Alcaligenes faecalis dan Pseudomonas aeruginosa. 
Tabel 1. Standart Diameter Zona Hambatan Antibiotika Yang Digunakan Pada Penelitian.

\begin{tabular}{clcccc}
\hline \multirow{2}{*}{ No. } & \multicolumn{2}{c}{ Nama Obat (Kode) } & Konsentrasi & \multicolumn{3}{c}{ Diameter Zona Hambatan (mm) } \\
\cline { 3 - 5 } & & & Resistan & Intermediet & Sensitif \\
\hline 1 & Amoxicillin Clavulanic Acid (AMC) & $30 \mu \mathrm{g}$ & $<15$ & $16-20$ & $>21$ \\
2 & Clindamycin (CC) & $2 \mu \mathrm{g}$ & $<15$ & $16-18$ & $>19$ \\
3 & Eritromycin (E) & $15 \mu \mathrm{g}$ & $<15$ & $16-20$ & $>21$ \\
4 & Ceftiaxone (CRO) & $30 \mu \mathrm{g}$ & $<13$ & $14-20$ & $>21$ \\
5 & Ciprofoxacin (CIP) & $5 \mu \mathrm{g}$ & $<15$ & $16-18$ & $>19$ \\
6 & Levofloxacin (LVX) & $5 \mu \mathrm{g}$ & $<13$ & $14-20$ & $>21$ \\
\hline
\end{tabular}

Hasil Uji Kepekaan Tiap sampel dapat dilihat dalam tabel berikut:

Tabel 2. Hasil Uji Kepekaan Tiap Sampel

\begin{tabular}{cclllllll}
\hline \multirow{2}{*}{ No. } & Inisial & & \multicolumn{7}{c}{ Jenis Kuman } & \multicolumn{7}{c}{ Antibiotika } \\
\cline { 4 - 8 } & Subjek & & AMC & $\mathrm{CC}$ & $\mathrm{E}$ & $\mathrm{CRO}$ & $\mathrm{CIP}$ & $\mathrm{LVX}$ \\
\hline 1 & $\mathrm{YL}$ & Staphylcoccus aureus & $\mathrm{S} / 30$ & $\mathrm{R} / 7$ & $\mathrm{I} / 19$ & $\mathrm{~S} / 26$ & $\mathrm{~S} / 27$ & $\mathrm{~S} / 27$ \\
2 & $\mathrm{LC}$ & Enterobacter aerogenes & $\mathrm{S} / 23$ & $\mathrm{R} / 7$ & $\mathrm{R} / 7$ & $\mathrm{~S} / 26$ & $\mathrm{~S} / 24$ & $\mathrm{~S} / 24$ \\
3 & $\mathrm{SD}$ & Staphylococcus epidermidis & $\mathrm{I} / 27$ & $\mathrm{R} / 7$ & $\mathrm{R} / 7$ & $\mathrm{R} / 7$ & $\mathrm{R} / 8$ & $\mathrm{R} / 8$ \\
4 & $\mathrm{NT}$ & Staphylococcus epidermidis & $\mathrm{I} / 17$ & $\mathrm{R} / 17$ & $\mathrm{R} / 7$ & $\mathrm{R} / 7$ & $\mathrm{R} / 8$ & $\mathrm{R} / 8$ \\
5 & $\mathrm{MS}$ & Enterobacter aerogenes & $\mathrm{R} / 18$ & $\mathrm{R} / 7$ & $\mathrm{R} / 7$ & $\mathrm{R} / 7$ & $\mathrm{R} / 7$ & $\mathrm{R} / 7$ \\
& & Tidak ada pertumbuhan & & & & & & \\
6 & $\mathrm{SW}$ & kuman & - & - & - & - & - & - \\
& & Tidak ada pertumbuhan & & & & & & \\
7 & $\mathrm{WP}$ & kuman & - & - & - & - & - & - \\
8 & $\mathrm{CT}$ & Staphylococcus epidermidis & $\mathrm{S} / 22$ & $\mathrm{I} / 19$ & $\mathrm{R} / 10$ & $\mathrm{~S} / 24$ & $\mathrm{I} / 16$ & $\mathrm{~S} / 20$ \\
9 & $\mathrm{GT}$ & Staphylococcus aureus & $\mathrm{I} / 17$ & $\mathrm{I} / 17$ & $\mathrm{I} / 17$ & $\mathrm{I} / 20$ & $\mathrm{I} / 16$ & $\mathrm{R} / 10$ \\
10 & $\mathrm{LP}$ & Proteus vulgaris & $\mathrm{R} / 10$ & $\mathrm{R} / 7$ & $\mathrm{R} / 7$ & $\mathrm{I} / 15$ & $\mathrm{R} / 10$ & $\mathrm{R} / 8$ \\
11 & $\mathrm{FD}$ & Enterobacter aerogenes & $\mathrm{S} / 21$ & $\mathrm{R} / 7$ & $\mathrm{R} / 7$ & $\mathrm{~S} / 23$ & $\mathrm{I} / 20$ & $\mathrm{~S} / 20$ \\
12 & $\mathrm{TN}$ & Staphylococcus epidermidis & $\mathrm{R} / 7$ & $\mathrm{R} / 7$ & $\mathrm{I} / 21$ & $\mathrm{~S} / 23$ & $\mathrm{~S} / 23$ & $\mathrm{~S} / 22$ \\
13 & $\mathrm{HP}$ & Citrobacter diversus & $\mathrm{I} / 15$ & $\mathrm{R} / 7$ & $\mathrm{I} / 21$ & $\mathrm{~S} / 24$ & $\mathrm{~S} / 22$ & $\mathrm{~S} / 20$ \\
14 & $\mathrm{DG}$ & Alcaligenes faecalis & $\mathrm{R} / 7$ & $\mathrm{R} / 8$ & $\mathrm{R} / 7$ & $\mathrm{I} / 19$ & $\mathrm{R} / 20$ & $\mathrm{R} / 7$ \\
15 & $\mathrm{TL}$ & Staphylococcus epidermidis & $\mathrm{R} / 7$ & $\mathrm{R} / 7$ & $\mathrm{R} / 8$ & $\mathrm{R} / 8$ & $\mathrm{I} / 8$ & $\mathrm{~S} / 21$ \\
16 & $\mathrm{WT}$ & Alcaligenes faecalis & $\mathrm{R} / 7$ & $\mathrm{~S} / 28$ & $\mathrm{R} / 7$ & $\mathrm{I} / 17$ & $\mathrm{~S} / 26$ & $\mathrm{~S} / 26$ \\
17 & $\mathrm{HB}$ & Staphylococcus aureus & $\mathrm{R} / 8$ & $\mathrm{R} / 7$ & $\mathrm{R} / 7$ & $\mathrm{I} / 17$ & $\mathrm{~S} / 23$ & $\mathrm{~S} / 26$ \\
18 & $\mathrm{JT}$ & Proteus vulgaris & $\mathrm{S} / 30$ & $\mathrm{R} / 7$ & $\mathrm{R} / 7$ & $\mathrm{~S} / 24$ & $\mathrm{I} / 20$ & $\mathrm{I} / 16$ \\
19 & $\mathrm{RE}$ & Staphylcoccus aureus & $\mathrm{S} / 30$ & $\mathrm{R} / 7$ & $\mathrm{I} / 19$ & $\mathrm{~S} / 26$ & $\mathrm{~S} / 27$ & $\mathrm{~S} / 27$ \\
20 & $\mathrm{SK}$ & Pseudomonas aeruginosa & $\mathrm{R} / 7$ & $\mathrm{R} / 7$ & $\mathrm{R} / 8$ & $\mathrm{I} / 15$ & $\mathrm{~S} / 22$ & $\mathrm{~S} / 18$ \\
\hline
\end{tabular}


Tabel 3. Persentase Kepekaan Bakteri Terhadap Beberapa Antibiotika

\begin{tabular}{lccccccc}
\hline Jenis Kuman & $\mathrm{n}$ & \multicolumn{7}{c}{ Kepekaan (\%) } \\
\cline { 3 - 8 } & & AMC & CC & E & CRO & CIP & LVX \\
\cline { 2 - 8 } Staphylococcus aureus & 4 & 50 & 0 & 0 & 25 & 25 & 25 \\
Enterobacter aerogenes & 3 & 66,7 & 0 & 0 & 66,7 & 33,3 & 66,7 \\
Staphylococcus epidermitis & 5 & 20 & 0 & 0 & 40 & 20 & 60 \\
Proteus vulgaris & 2 & 50 & 0 & 0 & 50 & 0 & 0 \\
Citrobacter diversus & 1 & 0 & 0 & 0 & 100 & 100 & 100 \\
Alcaligenes faecalis & 2 & 0 & 50 & 0 & 0 & 50 & 50 \\
Pseudomonas aeruginosa & 1 & 0 & 0 & 0 & 0 & 100 & 100 \\
\hline
\end{tabular}

Tabel 4. Persentase Resistensi Bakteri Terhadap Beberapa Antibiotika

\begin{tabular}{|c|c|c|c|c|c|c|c|}
\hline \multirow[t]{2}{*}{ Jenis Kuman } & \multirow[t]{2}{*}{$\mathrm{n}$} & \multicolumn{6}{|c|}{ Resistensi (\%) } \\
\hline & & AMC & CC & E & CRO & CIP & LVX \\
\hline Staphylococcus aureus & 4 & 25 & 75 & 25 & 0 & 0 & 25 \\
\hline Enterobacter aerogenes & 3 & 33,3 & 100 & 100 & 33,3 & 33,3 & 33,3 \\
\hline $\begin{array}{l}\text { Staphylococcus } \\
\text { epidermitis }\end{array}$ & 5 & 40 & 80 & 80 & 60 & 40 & 40 \\
\hline Proteus vulgaris & 2 & 50 & 100 & 100 & 0 & 50 & 50 \\
\hline Citrobacter diversus & 1 & 0 & 100 & 0 & 0 & 0 & 0 \\
\hline Alcaligenes faecalis & 2 & 100 & 50 & 100 & 0 & 50 & 50 \\
\hline Pseudomonas aeruginosa & 1 & 100 & 100 & 100 & 0 & 0 & 0 \\
\hline
\end{tabular}

Tabel 5. Persentase Intermediate Bakteri Terhadap Beberapa Antibiotika

\begin{tabular}{|c|c|c|c|c|c|c|c|}
\hline \multirow{2}{*}{ Jenis Kuman } & \multirow{2}{*}{$\mathrm{n}$} & \multicolumn{6}{|c|}{ Intermediate (\%) } \\
\hline & & AMC & CC & $\mathrm{E}$ & CRO & CIP & LVX \\
\hline Staphylococcus aureus & 4 & 25 & 25 & 50 & 50 & 25 & 0 \\
\hline Enterobacter aerogenes & 3 & 0 & 0 & 0 & 0 & 33,3 & 0 \\
\hline $\begin{array}{l}\text { Staphylococcus } \\
\text { epidermitis }\end{array}$ & 5 & 40 & 20 & 20 & 0 & 40 & 0 \\
\hline Proteus vulgaris & 2 & 0 & 0 & 0 & 50 & 50 & 50 \\
\hline Citrobacter diversus & 1 & 100 & 0 & 100 & 0 & 0 & 0 \\
\hline Alcaligenes faecalis & 2 & 0 & 0 & 0 & 100 & 0 & 0 \\
\hline Pseudomonas Aeruginosa & 1 & 0 & 0 & 0 & 100 & 0 & 0 \\
\hline
\end{tabular}

Dari hasil penelitian pada pasien yang memeriksakan diri ke Poliklinik THT-KL BLU RSUP Prof. Dr. R. D. Kandou Manado periode Desember 2012 - Januari 2013 di dapatkan 20 sampel dengan hasil 18 sampel positif menunjukan pertumbuhan kuman dan 2 sampel tidak ada pertumbuhan kuman.
Dari hasil distribusi berdasarkan umur, 20 orang pasien yang didiagnosis penderita otitis media dan dijadikan sampel rentan usia mulai dari 6 bulan sampai 77 tahun terdiri dari kelompok umur $<10$ tahun 11 pasien (55\%), kelompok umur 11-25 tahun 2 pasien (10\%), kelompok umur 26-40 tahun 3 pasien (15\%), kelompok umur 41-55 
tahun 1 pasien (5\%), dan kelompok umur $>55$ tahun 3 pasien (15\%). Hal ini menunjukkan bahwa yang tersering menderita penyakit otitis media yaitu pada bayi dan anak-anak. Teori juga mengatakan bahwa otitits media kebanyakan terjadi pada anak, dan hasil yang sama juga di dapatkan pada penelitan sebelumnya (Osazuwa F, et al. 2011) ditemukan penyakit otitis media yang tersering pada anak $(81,4 \%)^{8,9}$

Dilihat dari hasil distribusi pasien otitis media berdasarkan jenis kelamin, Pada 20 sampel penelitian terdapat 11 pasien perempuan (55\%) dan 9 pasien laki-laki (45\%). Hasil ini relatif sama dengan penelitian sebelumnya (Shrestha, et al. 2010) didapatkan hasil dari 230 penderita yang dijadikan sampel, perempuan 103 sampel (44,8\%) dan laki-laki 127 sampel (55,2\%).Hal ini perlu dilakukan penelitian lebih lanjut dengan sampel yang lebih banyak karena jumlah sampel mungkin bisa mempengaruhi peresentase hasil distribusi pasien berdasarkan jenis kelamin. ${ }^{10}$

Berdasarkan penelitian dari hasil biakan dan identifikasi kuman di Laboratorium Mikrobiologi BLU RSUP Prof Dr. R. D. Kandou Manado terhadap 20 sampel pasien yang memeriksakan diri ke Poliklinik THT-KL ditemukan 18 sampel yang menunjukkan pertumbuhan bakteri dan 2 sampel tidak menunjukkan pertumbuhan bakteri. Bakteri yang ditemukan terdiri dari Staphylococcus aureus 4 sampel (20\%), Enterobacter Aerogenes 3 sampel (15\%), Staphylococcus Epidermitis 5 sampel (25\%), Proteus vulgaris 2 sampel (10\%), Citrobacter diversus 1 sampel (5\%), Alcaligenes faecalis 2 sampel (10\%), dan Pseudomonas aeruginosa 1 sampel (5\%). Penelitian sebelumnya yang dilakukan (Osazuwa F, et al. 2011) Bakteri tersering yang di dapatkan pada otitis media yaitu; Pseudomonas Aeruginosa 132 sampel (28,3\%), Alcaligenes Faecalis 20 sampel (4.3\%), Citrobacter 8 sampel (1,7\%),
Proteus ssp 38 sampel (8.2\%), Staphylococcus Aureus 98 sampel (21,0\%). Perbedaan jumlah sampel, tempat dan waktu penelitian mungkin menjadi faktor penyebab.

Pada Uji Kepekaan digunakan 6 jenis Antibiotika yaitu Amoxicillin Clavulanic Acid, Clindamycin, Eritromycin, Ceftriaxsone, Ciprofoxacin, dan Levofloxacin. Hasil penelitian menunjukkan bahwa Levofloxacin dan Ciprofoxacin peka pada hampir semua bakteri yang terdapat pada sampel kecuali Proteus vulgaris. Antibiotika Ceftriakxone dan Amoxicillin peka terhadap Staphylococcus aureus, Enterobacter aerogenes, Staphylococcus epidermitis, Proteus vulgaris, dan citrobacter diversus. Kemudian antibiotika Clindamycin peka terhadap Alcaligenes faecalis (50\%), sedangkan antibiotika Eritromycin resistensi terhadap bakteri pada otitis media.

\section{SIMPULAN}

Dari hasil penelitian pada penderita otitis media di Poliklinik THT-KL BLU RSUP Prof. Dr. R. D. Kandou Manado periode Desember 2012 - Januari 2013 dapat disimpulkan bahwa sebagian besar memperlihatkan adanya pertumbuhan kuman dan bakteri yang diidentifikasi ialah Staphylococcus aureus, Enterobacter Aerogenes, Staphylococcus Epidermitis, Proteus vulgaris, Cibrobacter divertus, Alcaligenes falcelus, dan Pseudomonas aeruginosa. Hampir semua jenis bakteri yang diuji peka terhadap levofloxacin dan ciprofoxacin sedangkan clindamycin dan eritromycin telah menunjukkan tingkat resistensi yang cukup tinggi.

\section{SARAN}

Saran yang bisa diberikan yakni masih perlu dilakukan penelitian lebih lanjut tentang pola bakteri dan uji kepekaan pada penderita otitis media dengan sampel yang lebih banyak mengingat sering terjadi 
pergeseran pola bakteri yang didapatkan pada penderita otitis media dan resistensi tubuh terhadap antimikroba. Selain itu, dalam penanganan penderita otitis media hendaknya melakukan pengobatan secara teratur dan yang paling penting adalah kepatuhan penderita dalam hal meminum obat untuk mencegah terjadinya resistensi serta melakukan kontrol kesehatan agar tidak terjadi komplikasi lebih lanjut.

\section{DAFTAR PUSTAKA}

1. Muhammad F, Rahardjo S.P, Pieter N.A.L. Otitis Media Prevalence In Primary School Children In Makassar. The Indonesian Journal of Medical Science. Department of Oto-RhinoLaringology Lead and Neck Medical Faculty Hasanuddin University Wahidin Sudirohusodo Hospital. Makassar. 2010.

2. Akinjogunla O.J, Eghafona N.A, Enabulele I.O. Aetiologic Agents Of Acute Otitis Media (AOM): Prevalence, Antibiotic Suspectibility, $\beta$-Lactamase $(\beta \mathrm{L})$ And Extend Spectrum $\beta$ Lactamase (ESBL) Production. Journal of Microbiology, Biotechnology and Food Sciences. University of Uyo, Uyo, Faculty of Science. 2011.

3. Kamaludin D, Boesoirie T.S, Soeseno B, Purwanto B. Pengaruh Pemakaian Pipa Nasogastrik pada Kejadian Otitis Media Efusi. Departemen Ilmu Kesehatan Telinga, Hidung, Tenggorok - Bedah Kepala dan Leher. Fakultas Kedokteran, Universitas PadjadjaranRumah Sakit Hasan Sadikin. Bandung. MKB. 2011;43(1):42-8.

4. Wesliaprilius T.A. Hubungan Antara Otitis Media Supuratif Kronik Dengan Meningitis Di RSUP H. Adam Malik Medan. Fakultas Kedokteran Uiversitas Sumatera Utara. Medan. 2010.

5. Mansjoer A, Triyanti K, Savitri R, Wardhani W.I, Setiowulan W. Kapita
Selekta, dkk. $3^{\text {rd }}$ Ed. Media Aesculapius Fakultas Kedokteran Universitas Indonesia. Jakarta. 2001. Hal 79.

6. Nursiah S. Pola Kuman Aerob Penyebab OMSK Dan Kepekaannya Terhadap Beberapa Antibiotika di Bagian THT FK USU / RSUP.H. Adam Malik Medan. Program Pendidikan Dokter Spesialis Bidang Studi Ilmu Penyakit THT - KL. Fakultas Kedokteran Universitas Sumatera Utara. Medan. 2003.

7. Rupawan I.K. Pola Kuman Dan Kepekaannya Terhadap Antibiotika Pada Penderita Otitis Eksterna Di Poliklinik THT BLU RSUP Prof. Dr. R. D. Kandou Manado Periode Juni - Juli 2010. Fakultas Kedokteran Universitas Sam Ratulangi. Manado. 2010.

8. Pharmaceutical Care Untuk Penyakit Infeksi Saluran Pernapasan. Direktorat Bina Farmasi Komunitas dan Klinik. Direktorat Jendral Bina Kefarmasian Dan Alat Kesehatan. Departemen Kesehatan RI. 2005.

9. Osazuwa F. Etioligic Agents of Otitis Media in Benin City Nigeria. Department of Medical Microbiology, University of Benin Teaching Hosptal. North American Journal of Medical Sciences, 2011.

10. Shrestha B L. Microbiological Profile of Chronic Suppurative Otitis Media. Departement of ENT - HNS, Kathmandu University Hospital, Dhulikhel, Kavre, Nepal. Nepalese Journal of ENT Head and Neck Surger. 2011. 
